Kiss Gábor:

\title{
A természettudományos vizsgálatoktól az etikai prob- lémákig tartó fejlődés ellentmondásai
}

\author{
Boros Gábor: René Descartes \\ Áron Kiadó \\ Budapest, 1998, 339 oldal \\ $980 \mathrm{Ft}$
}

René Descartes-ot szokás a modernitás atyjának nevezni. Ez a meghatározás azonban csak egy a sok közül, hiszen elsösorban a filozófus Descartes-ot helyezi elötérbe. Azonban mást jelenít meg a XVII. század e nagy gondolkodójáról a fizika és megint csak mást a matematika. Az elóbbi a fénytörés törvényének egyik megfogalmazójaként, az utóbbi az analitikus geometria (koordinátageometria) egyik megalapozójaként tartja számon. A sok Descartes-kép mindegyike felmutat valamit abból, ami ezt a sokoldalú gondolkodót jellemezte. Ahhoz, hogy hủ képet kaphassunk róla, a sok értelmezési lehetőség mindegyikét érintenünk kell. Erre tesz kísérletet Boros Gábor, nemrégiben megjelent Descartes monográfiájában. Mielôtt rátérnénk ennek, a sok tekintetben hiánypótló, munkának a kritikai elemzésére, meg kell jegyezni, hogy a sok Descartes interpretációra a filozófus nagyon kiterjedt érdeklődési köre ad lehetőséget; aki egy átfogó képet szeretne adni Descartes-ról, annak a filozófus által vizsgált területek mindegyikében otthonosan kell mozognia.

A filozófia történetének egyik érdekes kérdése, hogy miért lesz néhány gondolkodó kiemelt jelentôségü, amíg más gondolkodók a háttérbe szorulnak. Erre talán az lehet a válasz, hogy a kiemelkedónek számító filozófusok gondolataiban megjelenik saját koruk, mint megoldandó probléma.
Ezek a problémák mindenképpen a társadalmiság szintjén keletkeznek. Gondoljunk csak Platónra, akinek gondolkodását a legtöbb esetben az Athénben megjelenő szofisták motiválták. Gondolatainak nagy része a szofista tanításokkal, illetve az azokból levonható következtetésekkel száll szembe. A problémákról elmondhatjuk, hogy a gyakorlat kérdésfeltevései. Ezek elméleti síkon jelennek meg, mint filozófiai problémák. A lehetséges megoldások filozófiai rendszerek keretében kapnak formát, amelyek értéke kizárólag a gyakorlat szempontjából méretik meg. Azok a rendszerek, amelyek megoldást kínálhatnak az adott kor problémáira, mint kiemelkedô gondolati rendszerek, alkotójuk pedig mint kiemelkedő gondolkodó ôrződik meg.

Descartes korának szellemi áramlatairól nagyon érzékletes képet kapunk Boros könyvének első oldalain. A bemutatott gondolatmozgások a reneszánsztól kapták az indíttatást. Nem véletlen, hogy a kor jelentôs alakjai elókerülnek a monográfiának ebben a részében. Szinte már kétségbeejtő az a sok új ismeret, amit a reneszánsz kora halmozott fel rövid idő alatt. Ennek kapcsán az olvasó csak kapkodja a fejét, hogy éppen kiról, miról is van szó az éppen adott oldalon. A reneszánsz korának, illetve az azt követő kor problémájának megfogalmazása Boros szavaival ekképp foglalható össze: „Az arisztotelészi és a platóni filozófia mellett a reneszánsz idején újjáéledtek a fó hellenisztikus irányzatok is, a sztoicizmus, epikureizmus és szkepticizmus." (26. o.). Ez utóbbival kapcsolatban bővebb tájékoztatást ad a 
monográfia is, talán, mert szerzóje is kiemelt problémának érzi a szkepticizmus újjáéledését.

Descartes filozófiájában található szkeptikus érveket illetve azok cáfolatával kapcsolatos problémákat ma is olyan érdeklődés övezi, mint megjelenésük idején. $\mathrm{Az}$ Elmélkedésekben található három szkeptikus érv közül már az Értekezés is tartalmaz kettôt. Mindenképp érdekes kérdés, hogy miként kerültek ezek a szkeptikus érvek Descartes filozófiájába. Úgy érzem Boros ebben a kérdésben mint még néhány más kérdésben is - válasz nélkül hagyja az olvasót. Ezzel a kérdéssel kapcsolatban két álláspont jelenik meg Boros érvelésében. Az egyik szerint, mint már idéztük, a reneszánsz korának egyik újjáéledő filozófiai irányzata a szkepticizmus volt, aminek egyik jól ismert kifutási lehetősége minden tudás, és ennek következtében, minden tudomány lehetőségét megkérdőjelezi. Amikor a szkepticizmus - talán hangsúlyosan is - jelen van, az elóbb mondottak következtében, egy Descartes típusú gondolkodó figyelmét nem kerülheti el. Hiszen Descartes éppen a tudományokban akart maradandót alkotni. Boros, 203. oldalon megfogalmazott, véleménye szerint - ami a másik lehetséges álláspont arra vonatkozóan, hogy miért jelenik meg a szkepticizmus Descartes filozófiájában - a szkepticizmusra csak egy 1634-35 telén elhangzott előadás hívta fel Descartes figyelmét. Egy ilyen kijelentés azt hiszem Descartes helyzetértékelő képességét veszi semmibe. Még érdekesebbé teszi a helyzetet, hogy Boros a - 180. oldalon - kijelenti: Descartes az Értekezések megírása előtt „/m/ár közel két évtizede érleli magában egy egységes, az emberi természetet tökéletesítő tudományra vonatkozó gondolatait." Vajon e két évtized alatt nem találkozott a filozófus a hangsúlyosan jelenlévô szkepticizmussal, vajon nem gondolta át annak, tö-

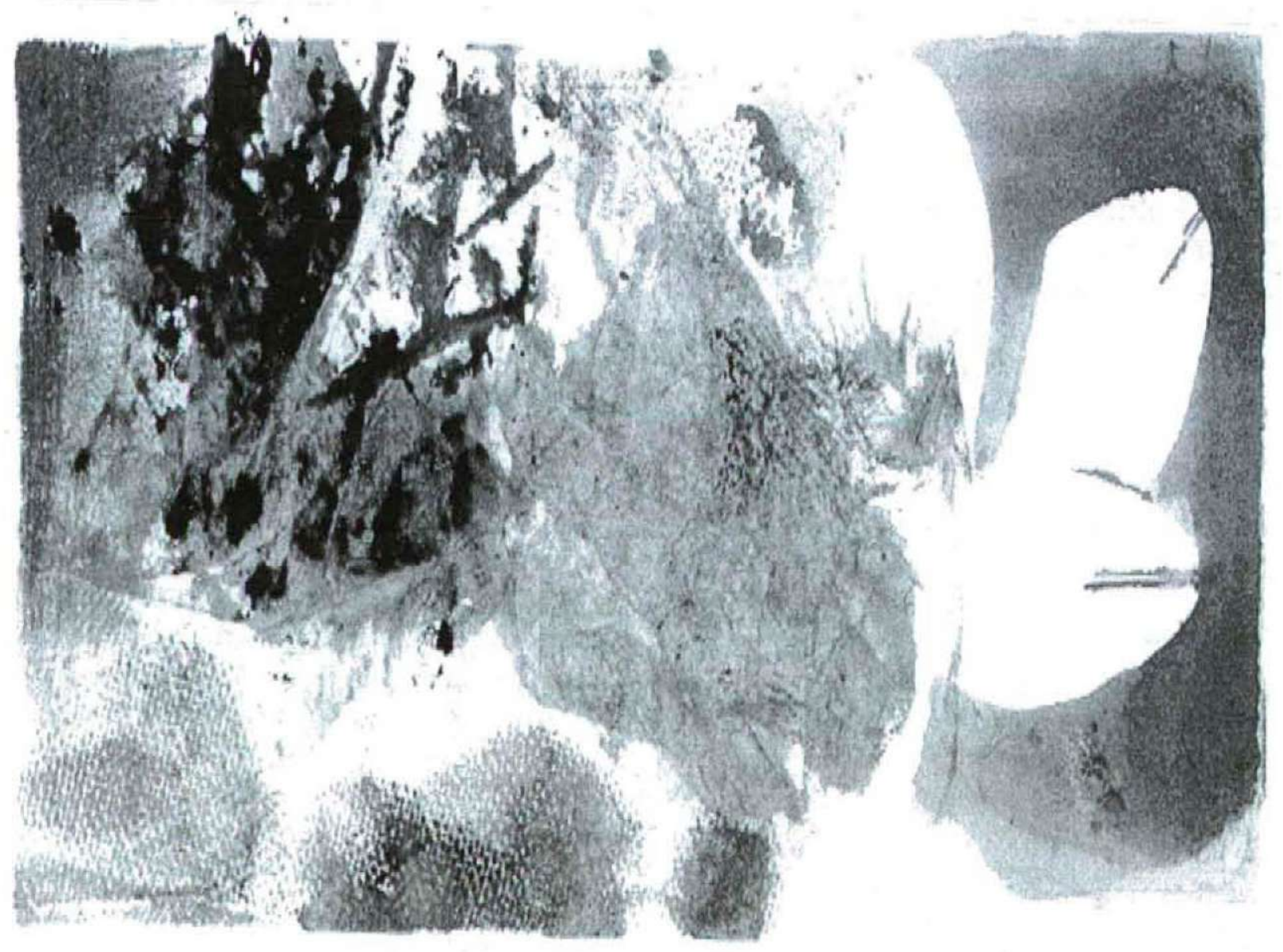


rekvéseire vonatkozó, következményeit? Tényleg csak egy skót lelkész lett volna képes ráébreszteni Descartes-ot a szkepticizmus kihívására?

A két bemutatott álláspont - mint a hivatkozott oldalszámok mutatják - a monográfia két eltérő helyéról származik. Ezért nem két ütköztethető álláspontként, hanem mint két egyenértékű, védhető álláspont jelenik meg. A két álláspont - az ambivalencia veszélye nélkül - nem foglalható el. Ezért mondható, hogy Boros magára hagyja az olvasót ilyen kérdésekben. Ezek kapcsán felmerülhet az olvasóban a kérdés, hogy nem bonyolódott-e maga Boros is ellentmondásokba, amikor a descartes-i filozófiában fellelhetô ellentmondásokat igyekszik kimutatni?

A fentiek kapcsán elmondható, hogy a monográfiát jellemzi egy törekvés, ami arra irányul, hogy megfossza Descartes-ot a filozófiai-bálvány státusztól. Ennek egy másik megnyilvánulási formája, hogy a bemutatott kortársak között néha el is veszítjük filozófusunkat. Ezzel azonban nem foglalkozunk részletesebben, mert nem bevallott célja a szerzónek, de annyit érdemes még megjegyezni, hogy a munka a Nagy Gondolkodók (!) sorozatban (?) jelent meg. Szólnunk kell azonban Boros kimondott programjáról, ami nem más mint a descartes-i fejlődés bemutatása.

A szerző Descartes életművét három szakaszra bontja aszerint, hogy az egyes korszakok írásaiban mely területek domináltak. Így a fejlődést a tudomány (fizika, matematika) - metafizika - etika vonulatban értelmezi. Azt hiszem ez a séma túlságosan eróltetett. Elegendő itt csak az Alapelvek ismeretelméleti vagy természettudományos jellegú részeire felhívni a figyelmet, hogy lássuk, az Alapelvek nem sorolható be egyértelmúen az etikai vizsgálódások területére. A szerző által javasolt séma tarthatatlanságára utaló jelek azonban már 'Az első alkotói korszak' című fejezetben is fellelhetók. A szövegnek ezen a helyén elviselhetetlenül sok az ,ezt a problémát a késóbbiekben tárgyaljuk részletesen" típusú utalás, amelyek a második és harmadik alkotói korszakot tárgyaló részre jelentősen megfogyatkoznak. A séma eróltetett jellegét jelzi továbbá az is, hogy a szerző igyekszik kerülni az ismeretelméleti kérdéseket a második és harmadik szakaszt bemutató részekben, de nyilvánvalóvá válik, hogy nem kerülheti meg óket. Mindenképpen pozitívum, hogy nem is kerüli meg óket.

Megfigyelhető továbbá egy jelentős aránytalanság a Boros által vázolt koncepcióban. Ez mennyiségileg és minőségileg is megnyilvánul. Ami a mennyiségi oldalt illeti. A legnagyobb figyelmet - oldalszám tekintetében - az Értekezés és az Elmélkedések kapja. Talán tényleg ez a két mú a legfontosabb, fóleg ha fontosságukat a „korai naplóbejegyzésekhez” viszonyítjuk. El is fogadnánk ezt az álláspontot, amennyiben Boros nem jelentené ki - a 321. oldalon - az Alapelvekkel kapcsolatban: „Vitathatatlan, hogy a descartes-i életmú egyik legfontosabb darabjáról van szó." A kérdés csak az, miért nem kapja meg az Alapelvek a neki járó „vitathatatlan” terjedelmet? Ez az elkülönülés megfigyelhetô a tárgyalási módokban is. Boros az Értekezéssel és az Elmélkedésekkel kapcsolatosan saját - korántsem kimerítő - értelmezését adja. A fennmaradó múveket a művekre vonatkozó kommentárok alapján mutatja be. Kérdéses ennek a szelekciónak az elve is.

Ezek kapcsán azt hiszem elmondható, hogy a kitűzött programot ebben a formában nem sikerült a szerzőnek megvalósítani. Ugyan felismerhető a bemutatni kívánt folyamat, de nem sikerül meggyőző érveket felhozni amellett, hogy a folyamat tényleg a vázolt keretek között zajlott. Az elmondottak kapcsán az is felmerülhet az olvasóban, hogy ez a folyamat nem is mutatható ki meggyőző erővel. Talán jobb lett volna dönteni a tárgyalási mód egyik vagy másik formája mellett - ti. vagy más kommentátorok véleményének ütköztetése 
vagy saját értelmezés adása. A kettő együtt azt a látszatot kelti, hogy a vázolt koncepciót nem támogatja egyik megoldási mód sem.

A könyv formai része azt sugallja, hogy ez a munka valamiért nagy sietség közepette jelent meg. Sajnos a bosszantóan sok sajtóhiba mellett az igen hosszú - néha alig érthetô mondatok - is rontanak a vállalkozás értékén. Ennek talán az egyik legelrettentóbb darabja a következő - 77 . oldalon található - mondat.

\begin{abstract}
„A korábban már említett Claude Mydorge, akit elsősorban a tükrök optikai tulajdonságainak vizsgálata foglalkoztatott valamint Jean Ferrier, aki kifejezetten lencsecsiszolással foglalkozott, s egy olyan lencsét csiszolt számára, amely a beesô fénysugarakat a gyújtópontban egyesítette, voltak azok, akik a korábbi, a Cognitationes privatae bizonyos optikai megjegyzései által tanúsított optikai érdeklődését oly mértékben fejlesztették tovább benne, hogy valamikor 1628 elött, a holland Willenbord Snelliusszal közel egyszerre, ő is felfedezte az egyik közegból a másikba kerülő fénysugarak megtörésének törvényét."
\end{abstract}

A kapkodásra utal az is, hogy a szerző az 54. oldalon a következóket írja: „Aritmetikai egy 'arányosság' - mai nyelven inkább 'haladvány' - akkor, ha a mindenkori következő számhoz úgy jutunk el, hogy az előzô számhoz mindig azonos mennyiséget adunk.” Kis utánajárással kiderül, hogy az arányosság - „mai nyelven inkább” - sorozat és nem haladvány, aminek elemeiként ugyan számokat kaphatunk, de a sorozatokban elemekból elemeket kapunk.

A problémát nem csak az jelenti, hogy ilyen mondatok és pontatlanságok eloofordulnak múben, hanem az, hogy Borostól nem ezt szoktuk meg. Korábbi munkái alapján egy színvonalas munkát vártunk, ez azonban messze elmarad a korábbi színvonaltól. Amikor a vásárló kezébe vesz a szerző nevével fémjelzett könyvet, örül, hogy ilyen - relatíve - olcsón kaphat monográfiát Descartes-ról... Emellett meg kell jegyezni, hogy a kötet egyetemi tankönyvként jelent meg. Amennyiben egy egyetemi tankönyv célja a kritikai érzék ébrentartása, úgy ezt a célját elérte.

A kötet azonban mindenképpen megerősíti azt a meggyőződésünket, hogy nem lehet és nem is érdemes Descartes-ról átfogó képet adni úgy, hogy ne ismernénk azokat a vizsgálódási területeket, amelyekkel Descartes foglalkozott. Nem tehetünk mást, várjuk annak - az előszóban beígért kötetnek a megjelenését, amely szisztematikusan igyekszik bevezetni az érdeklődôt Descartes filozófiájába.

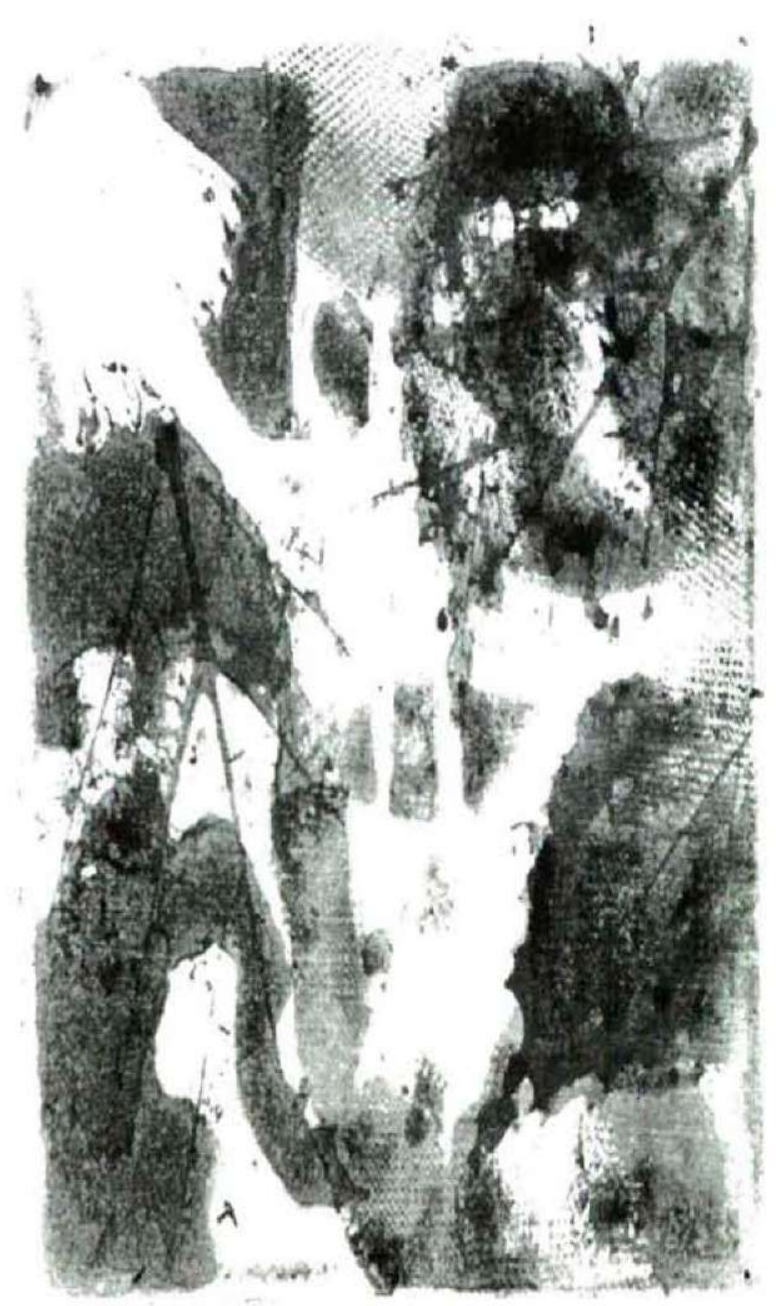

